\title{
ADOPTION EFFECT OF CROP MANAGEMENT PRACTICES ON THE TECHNICAL EFFICIENCY OF MA1ZE FARMERS IN SOUTH WESTERN NIGERIA
}

\author{
${ }^{1}$ OLAPADE-OGUNWOLE, Folayimi*, ${ }^{2}$ TAIWO, John Olayinka and ${ }^{3}$ OJEDOKUN, Idris Kayode \\ ${ }^{1}$ Department of Agricultural Economics, Ladoke Akintola University of Technology, Ogbomoso, Oyo, Nigeria. \\ ${ }^{2}$ Ladoke Akintola University of Technology, Ogbomoso, Oyo, Nigeria. \\ ${ }^{3}$ Department of Agricultural Economics, Ladoke Akintola University of Technology, Ogbomoso, Oyo, Nigeria. \\ http://doi.org/10.35410/IJAEB.2019.4411
}

\begin{abstract}
Adoption of improved maize production technologies and management practices has received much attention in recent years because of increase in the demand for maize. Over the years however, the recorded maize yield of an average Nigeria farmer has not been able to match the efforts put into effectively make use of modern production technologies and management practices. The need therefore the examine improved maize production technologies is-a-vis some management practices becomes pertinent in order to identify th factors responsible for the inefficiency of maize farmers. This research therefore focused on the adoption effects of crop management practices on the technical efficiency of maize farmers in Oyo and Osun States Nigeria.

A multistage sampling technique was used in collecting data from a cross-sectional sample of 300 maize farming households in Oyo and Osun States. Descriptive statistics (means, frequency counts, percentages, etc.) Data Envelopment Analysis (DEA) Tobit regression analysis were employed in analyzing the data. Results from the Tobit analysis showed that adoption is determined by gender $(\mathrm{p}<0.05)$, years spend in school $(\mathrm{p}<0.1)$ marital status $(\mathrm{p}<0.05)$ and access to extension training $(\mathrm{p}<0.1)$.

The average overall technical efficiencies for farmers in Oyo State were 41.6 and 69.5 respectively for Constant Returns to Scale, Variable Returns to Scales and Scale Efficiency while for Osun State; these were 39,66.6 and 61.5 for CRS, VRS and scale efficiency respectively. These results revealed that substantial inefficiencies exist in the farming operations of the two states. The return to scale, where the sub-optimal (VRS), optimal (CRS) and super optimal (DRS) are considered for Oyo State respondents were $88 \%, 8.7 \%$ and $3.3 \%$ of the farmers were respectively. For Osun State respondents, $89.3 \%, 2.7 \%$ and $8 \%$ of the farmers were sub-optimal, optimal and super-optimal respectively.
\end{abstract}

Keywords: Adoption, maize DEA, Tobit, South-western.

\section{INTRODUCTION}

Maize has been cultivated in Nigeria for hundreds of years. According to Morris et. al. (1999) since the introduction of maize in the 16th century, it has established itself as an important food 
crop in the country. In no time, maize also attracted the attention of commercial farmers, even though it never achieved economic importance as compared with traditional plantation crops, such as oil palm and cocoa. Over time, the Roding profitability of many plantation crops (attributable many to increasing disease problem in cocoa, deforestation and natural resource degradation, and falling world commodity prices) served to strengthen interest in commercial food crops, including maize (Morris et al., 1999). According to Al-Hassan and Jatoe (2002) maize is currently Nigeria's most important cereal crop. It is grow by the vast majority of rural households in almost all parts of the country except for the Sudan Savanna Zone of the North, it is grown exclusively as a food crop (Akinwumi, 1970).

Nigeria is currently the tenth largest producer of maize in the world, and the largest maize produce in Africa (IITA, 2012). Also it is estimated that over seventy percent of farmers are smallholders accounting for 90 percent of total farm output (Cadini, P and Angelucci F, 2013).

\section{MATERIAL AND METHODS}

The study was carried out in Southwestern part of Nigeria precisely Oyo and Osun states. The population of the study comprises all registered maize producing farmers in all agricultural zones under Oyo and Osun States Agricultural Development Projects (OYSADEP) and (OSSADEP) respectively. For administrative convenience four agricultural zones and thirty three (33) blocks were found in OYSADEP while three agricultural zones and thirty (30) blocks are in OSSADEP.

The Agricultural zones in Oyo states are Ibadan /Ibarapa (14blocks), Ogbomoso (5 blocks) Oyo (5 blocks) and Saki (9 blocks) and those of Osun state include Osogbo (13 blocks/Ife/Ijesha (10 blocks) and Iwo (7blocks). Three agricultural zones were purposively selected from each state making six (6) zones in total, based on the type of crops grown. These were Ogbomoso, Oyo and Saki zone from Oyo state and Ife /Ijesha, Iwo and Osogbo zones from Osun state.

Multistage random sampling technique was employed to sample three hundred (300) maize farmers. In the first stage, 30 percent of the blocks were randomly selected from each of the six agricultural zones. A total of sixteen blocks were sampled and each block comprises eight cells. Second stage involves random selection of 30 percent of the cells, two (2) in each block making a total of 32 cells for the study. Finally, 20 percent of the maize farmers in each cell were randomly selected for the study.

\section{Empirical DEA Model}

Given that there is an underlying production technology, technical as well as scale efficiencies can be estimated empirically. For a sample of $n$ observations of farm households using $k$ input to produce $m$ outputs the input and output vectors for the $i$ th household can be represented as $\left(X_{k i}\right)$ and $\left(Y_{m i}\right)$ respectively. For a household using $\left(X_{k i}\right)$ to produce $\left(Y_{m i}\right)$ the inputoriented technical efficiency estimate is defined by:

$T E\left(X_{k i}, Y_{m i}\right)=\underset{\theta, z}{\operatorname{Min}} \theta\left(\theta, X_{k i}, Y_{m i}\right)$ 
Subject to $\left\{\begin{array}{l}y_{m i} \leq \sum_{j=1}^{I} y_{m i}, m=1,2, \ldots, M \\ \sum_{j=1}^{I} Z_{i} x_{k i} \leq k=1,2, \ldots, K \\ z_{1} \geq 0, i=1,2, \ldots \ldots, I\end{array}\right\}$

where $\theta_{I}=$ technical efficiency estimate to be calculated for each farm household $i, y_{m i}=$ quantity of output $m$ produced by farm household $i, x_{k i}=$ quantity of input $k$ used by farm household $i, z_{i}=$ intensity variable from household $i$, A household is considered to be technically efficient if $\theta=1$, while a household with $\theta<1$ is considered to be technically inefficient. The model above assumes constant returns to scale (CRS), which holds that all firms (farm households) operate at the optimum scale (Mugera and Featherstone, 2008). However, because of imperfections in agricultural markets (input/output markets) farms seldom operate under CRS, imposes variable returns to scale (VRS).

$\sum_{j=1}^{I} Z_{i}=1$
$\sum_{j=1}^{I} Z_{i}<1$

3. RESULT AND DISCUSSION

Technical and scale efficiency Indices of Farmers in both States (pooled)

The technical and scale efficiency distribution and frequency level for the pooled data collected from both states (Osun and Oyo State) are shown.

The efficiencies means were 33.3 percent, 65.7 percent and 61 percent for CRS, VRS and scale efficiency respectively. The fully technically efficient farmers were 3.7 percent, 14.3 percent and 3.7 percent for CRS, VRS and scale respectively. While, the minimum and maximum for CRS, VRS and scale were 1001,100 and 20 and 100 and 1 respectively. Observing their means, it was deduced that there is still more rooms for adjustment by improving on the use of the improved technologies at appropriate time and level.

Frequency Distribution of Oyo Technical and Scale Efficiency Indices of Farmer

\begin{tabular}{|lllllll|}
\hline $\begin{array}{l}\text { Efficiency } \\
\text { Score }\end{array}$ & $\begin{array}{l}\text { Technical } \\
\text { Efficiency } \\
\text { at CRS }\end{array}$ & Percentage & $\begin{array}{l}\text { Technical } \\
\text { Efficiency } \\
\text { at VRS }\end{array}$ & Percentage & $\begin{array}{l}\text { Scale } \\
\text { Efficiency }\end{array}$ & Percentage \\
\hline $0-9$ & 10 & 3.3 & 0 & 0 & 8 & $\mathbf{2 . 7}$ \\
$10-19$ & 48 & 16 & 0 & 0 & 17 & $\mathbf{5 . 7}$ \\
$20-29$ & 94 & 31.3 & 22 & 7.3 & 19 & $\mathbf{6 . 3}$ \\
$30-39$ & 63 & 21 & 78 & 26 & 26 & $\mathbf{8 . 7}$ \\
$40-49$ & 29 & 9.7 & 45 & 15 & 26 & $\mathbf{8 . 7}$ \\
$50-59$ & 22 & 7.3 & 56 & 18.7 & 35 & $\mathbf{1 1 . 7}$ \\
$60-69$ & 6 & 2 & 23 & 7.7 & 47 & $\mathbf{1 5 . 7}$ \\
$70-79$ & 5 & 1.7 & 8 & 2.7 & 47 & $\mathbf{1 1 . 7}$
\end{tabular}




\begin{tabular}{|lllllll|}
\hline $80-89$ & 5 & 1.7 & 11 & 3.7 & 31 & $\mathbf{1 0 . 3}$ \\
$90-99$ & 7 & 2.3 & 14 & 4.7 & 33 & $\mathbf{1 1}$ \\
100 & 11 & 3.7 & 43 & 14.3 & 11 & $\mathbf{3 . 7}$ \\
\hline Total & $\mathbf{3 0 0}$ & $\mathbf{1 0 0}$ & $\mathbf{3 0 0}$ & $\mathbf{1 0 0}$ & $\mathbf{3 0 0}$ & $\mathbf{1 0 0}$ \\
\hline Mean & 33.3 & & 56.0 & & 61 & \\
Maximum & 100 & & 100 & & 100 & \\
Minimum & 1 & & 20 & & 1 & \\
\hline
\end{tabular}

Source: Field Survey: 2017.

\section{Characteristics of Farmers with Respect to Returns to Scale}

Observing the scale efficiency for the pooled data which was 61 percent, it shows the efficiency is still considerable. From the overall 300 farms pooled together, 275 farms were suboptimal (CRS), 11 farms were optimal (CRS) and 14 farms were super optimal (DRS). This shows that we still have little percentage of farms which still use their resources optimally and larger percentages did not use the resources optimally.

\section{Characteristics of Farmers with Respect to Return to Scale}

\begin{tabular}{|lll|}
\hline Scale & Number of farmers & Percentage \\
\hline Sub optimal (IRS) & 275 & 91.7 \\
Optimal (CRS) & 11 & 3.7 \\
Super-optimal (DRS) & 14 & 4.6 \\
\hline Total & $\mathbf{3 0 0}$ & $\mathbf{1 0 0}$ \\
\hline
\end{tabular}

Source: Field Survey, 2017.

IRS - Increasing Returns to Scales

CRS - Constant Returns to Scale

DRS - Decreasing Returns to Scale

\section{Summary of Output and Input Slacks of Farmers}

From the pooled results, the pooled farmers can increase their maize output by $17.6 \mathrm{~kg}$ given all available operation and technologies with the resources. Also they can reduce on average, the input usage of $0.052 \mathrm{ha}$ of land size, $1.53 \mathrm{~kg}$ of maize seeds, 3.09Manday of family labour, $\$ 9079.53$ of hired labour, $\$ 9,082.63$ of quantity of fertilizer used and $\$ 18,162.16$ of chemical and still produce maximally the output of maize.

Summary of Output and Input Slacks of Farmers

\begin{tabular}{|lll|}
\hline Input-Output & Number of farmers & Mean Slacks \\
\hline$x_{1}$ (maize seed) & 40 & 1.530 \\
$x_{2}$ (farm size) & 7 & 0.052 \\
$x_{3}$ Manday (family labour) & 99 & 3.093 \\
$x_{4}$ (hired labour) & 171 & 9079.53 \\
$x_{5}$ (Quantity of fertilizer) & 203 & 9082.63
\end{tabular}




\begin{tabular}{|lll}
$x_{6}$ (Quantity of chemical) & 205 & 18162.16 \\
$y$ (maize output) & 20 & 17.599 \\
\hline
\end{tabular}

Source: Computed From Field Survey: 2017.

\section{TOBIT ESTIMATES OF DETERMINANT OF EFFICIENCY OF ALL FARMERS}

\section{Estimated Tobit Model for Oyo State}

From the analyzed Tobit using the following variables, Age, Gender, Years of Schooling, Household Size, Frequency of extension visit, years of experience farm size, Access to extension training using a binary mode either 1 or 0 and actual for ages, years of experience, household size etc. out of the nine variables analyzed, five were significant at various levels.

Gender was significant at 5 percent and positive which showed that male which is 1 is more active and dominate the farming system and it could be due to the strenuous work and this helps in adopting the various improved technologies.

Marital status was significant at 5 percent but negative. From the analysis married was 1 , unmarried -0 . This results showed that the unmarried were involved more in the adoption of the technologies compared to their counterparts. And this can be that they have less marital responsibility than their counterpart. Years of experience were significant at 1 percent and negative. This reveals that the more experienced the farmers are the more they believe and adopt their primitive and ancient methods of production. Farm size was significant at 5 percent and positive, this encourages farmers to procure enough land spaces to improve their technologies. Access to extension training was significant at 5 percent and positive. This revealed that the extension training given to the farmers in adopting the improved technologies have positive effect on their production. The sigma shows a significant level and this shows the result has a good fit.

\section{Tobit Marginal Effect}

The marginal effect was presented in the table, gender, years spent in school, marital status and access to extension training all have positive relationship with adoption index and are significant at 5\%,10\%,5\% and $1 \%$ levels respectively. The coefficient of 0.944 in the table for access to extension training means that, holding other variables constant, if farmers are aware of the improved technologies, and have access to extension training, the level of improvement or the direct change on the adoption of the technology will at $94.4 \%$.

The coefficients of frequency of extension visit. Household size, years of farming experience and farm size were positive but not statistically significant. Therefore, the frequency of extension visit, household size, years of farming experience and farm size increases as the adoption index for the improved technologies increases. However, the coefficient of age was negative and not statistically significant.

Tobit Regression Results (Marginal Effects)

Adoption Index as dependent variable

\begin{tabular}{|llll|}
\hline Coeff. & Std. Err. & p-values & Marginal Effects \\
\hline
\end{tabular}


Vol. 4, No. 04; 2019

ISSN: $2456-8643$

\begin{tabular}{|lllll|}
\hline Age & -0.00469 & 0.00407 & 0.252 & 0.251 \\
Gender & 0.201 & 0.0686 & 0.004 & $0.003^{* *}$ \\
Years spent in School & 0.0104 & 0.006 & 0.095 & $0.094^{*}$ \\
Marital Status & 0.1103 & 0.0545 & 0.044 & $0.043^{* *}$ \\
Household Size & 0.00673 & 0.122 & 0.581 & 0.580 \\
Frequency of Extension Visit & 0.0121 & 0.026 & 0.645 & 0.644 \\
Years of Farming Experience & 0.000415 & 0.00369 & 0.910 & 0.910 \\
Farm Size & -0.0212 & 0.0129 & 0.271 & 0.270 \\
Access to Extension Training & 0.9444 & 0.146 & 0.000 & $0.000^{* * *}$ \\
Constant & -0.127 & 0.250 & 0.612 & \\
Number of Observation & 300 & & & \\
LRCh^2 & 66.63 & & & \\
Pseudo R2 & 0.6570 & & & \\
\hline
\end{tabular}

$* * * 1 \%$ level of significance, $\quad * * 5 \%$ level of significance and $* 10 \%$ level of significance

Source: Computed From Field Survey: 2017.

\section{CONCLUSION}

They study concluded that awareness of and access to extension training have positive impact on the adoption of the improved maize technologies and crop management practices. In addition gender, years spent in school, marital status and access to extension training all have positive relationships with adoption index. Generally, the adoption of and compliance to one or more crop management practices improves farmers' technical efficiency, encouraging farmers to strictly adhere to these practices is a way forward in the bid by stakeholder to ensure increase in agricultural productivity.

\section{REFERENCES}

Cadini D. and Angelucci F. (2013). Analysis of Incentive and Disincentive for Maize in Nigeria. Monitoring African Food and Agricultural Policies (MAFAP). Technical Report Series MAFAP/FAO Rome. Pp. 41.

IITA (2012). International Institute for Tropical Agriculture. Growing in Nigeria, Commercial Crop Production Guide Series. Information and Communication Support for Agricultural Growth in Nigeria USAID Pp. $1-8$.

Akinwumi J.A (1970). Economics of Maize Production in Oyo Division, Western State, Nigeria. Unpublished MSc Thesis, Department of Agricultural Economics, University of Ibadan. 
Kinwusi J.A. (1991). "Bridging the Technologies gap in Nigeria's Agricultural Product" Proceedings of the National Conference of Ibadan Socio-Economics Group on Development Strategies in 21st Century Nigeria.

Al-Hassan R., and Jatoe J.B.D. (2000). "Adoption and Impact of Improved Cereal Varieties in Ghana Paper Presented at Workshop on the Green Revolution in Asia and Its Transferability of Africa, December 2002. TOKYO, Japan.

Morios, M.L. Tripp, R. and Dankyi, A.A. (1999). Adoption and Impacts of Improved Maize Production Technology. A case study of the Ghana Greens Development Project, Economics Program Paper 99 - 01 Mexico D. F., CIMMYT. Available oline http:/www.Cimmy. 